\title{
The Level of Heat Shock Protein 70 is Lower in Postterm Pregnancy
}

\section{Kadar Heat Shock Protein 70 Kehamilan lebih Rendah pada Kehamilan Pascamatur}

\author{
Soetrisno \\ Department of Obstetrics and Gynecology \\ Faculty of Medicine University of Sebelas Maret/ \\ Dr. Moewardi Hospital \\ Surakarta
}

\begin{abstract}
Objective: To analyze whether there are differences between the levels of HSP70 of Postterm pregnancy and aterm pregnancy in Dr. Moewardi Hospital, Surakarta, Central Java.

Method: This was a cross-sectional study. The independent variable was the level of Heat Shock Protein 70 (HSP70), and the dependent variable was the incidence of postterm pregnancy. The data was then analyzed by t test.

Result: The subjects were 45 women, who were divided into 2 groups of women with postterm pregnancies (15 women) and aterm pregnancies (30 women). The mean levels of HSP70 in the serum of women with postterm pregnancy is lower $(0.40 \mathrm{ng} / \mathrm{ml}) \mathrm{com}$ pared to the level of the normal pregnant group $(3.94 \mathrm{ng} / \mathrm{ml})$ and this difference was statistically significant $(\mathrm{p}<0.001)$.

Conclusion: The mean level of HSP70 in postterm pregnancy is lower than in normal full-term pregnancy.

[Indones J Obstet Gynecol 2014; 2-1: 28-32]

Keywords: Heat Shock Protein 70, Maternal Stress, postterm pregnancy
\end{abstract}

\begin{abstract}
Abstrak
Tujuan: Untuk menganalisis apakah ada perbedaan kadar HSP70 antara kehamilan lewat waktu dan kehamilan aterm di RSUD Dr. Moewardi, Surakarta, Jawa Tengah.

Metode: Penelitian observasional analitik dan desain penelitian potong lintang. Variabel independen adalah kadar HSP70, sementara variabel dependen adalah kehamilan pascamatur. Analisa statistik dilakukan dengan uji t.

Hasil: Jumlah subjek penelitian adalah 45 orang, terbagi ke dalam 2 kelompok yaitu kelompok kehamilan postterm (15 orang) dan kelompok kehamilan normal (30 orang). Rerata kadar HSP70 pada serum ibu hamil dengan kehamilan postterm lebih rendah $(0,40 \mathrm{ng} / \mathrm{ml}) \mathrm{di}$ bandingkan dengan kelompok hamil normal $(3,94 \mathrm{ng} / \mathrm{ml})$ dan perbedaan tersebut secara statistik bermakna $(p<0,001)$.

Kesimpulan: Rerata kadar HSP70 pada kehamilan postterm didapatkan lebih rendah dari pada hamil aterm normal dan perbedaan ini bermakna secara statistik.

[Maj Obstet Ginekol Indones 2014; 2-1: 28-32]

Kata kunci: Heat Shock Protein 70, kehamilan postterm, stres maternal
\end{abstract}

Correspondence: Soetrisno. Department of Obstetrics and Gynecology Faculty of Medicine Sebelas Maret University, Surakarta. Telephone: 081329677702, Email: pogi_surakarta@yahoo.co.id; robby_2801@yahoo.com

\section{INTRODUCTION}

The pathogenesis of postterm pregnancy still remains a mystery. The exact mechanisms involved in the initiation of labor in humans is still unknown. Delivery process occurs due to loss of uterus' composure, induction of uterine muscle contractility or a combination of both. During pregnancy, it is important for the uterus is in a stressfree condition so that the fetus can grow and develop in preparation for life outside that womb. ${ }^{1}$ Initiation of normal delivery is the result of interaction between maternal, fetal and endocrineautocrine-paracrine placental system. The mechanism involves a complicated positive and negative feedback, cellular receptor regulation and chemical messengers dynamic system. The sequence of events that culminated in the maturation of the fe- tus and uterine tissue occurs subsequent to initiation of labor. ${ }^{2}$

Postterm pregnancy causes post maturity syndrome and placental dysfunction. Incidence of post maturity syndrome in infants born at gestational age 41,42 or 43 weeks could not be determined with certainty until now. Approximately $10 \%$ of post maturity syndrome occurs between the ages of 41 and 43 weeks gestation, whereas the incidence increased to up to 44 weeks of gestation. The incidence of events is in accordance to the incidence ofoligohydramnions. 3,4

The concept that post-maturity syndrome is caused by placental insufficiency is still believed, despite the absence of meaningful morphological or histological placental findings. Placental apoptosis rate increased significantly at 41 weeks to 42 
weeks gestation compared to the rate at 36 weeks of gestation to 39 weeks. Fetal oxygen requirement increases with aging placenta in postterm pregnancy. Decrease in the partial pressure of oxygen is the only event that is known to stimulate the secretion of erythropoietin. At the time of the study of uncomplicated postterm delivery, umbilical cord erythropoietin levels increased significantly in the approaching 41 weeks gestation or more. Although Apgar scores and umbilical cord blood gas analysis in the normal range for babies from postterm pregnancy, however, some researchers conclude that there is a decrease in fetal oxygenation on some postterm pregnancy. ${ }^{3,4}$

Socio-economic status is a complex construction, generally used to define social diversity and usually measured by the achievement of income and/or education. Education is one of the dimensions of socioeconomic status, which most strongly and consistently can predict health outcomes. Mother's education is the most powerful predictor of the reproductive outcome in studies in the United States. Low education will limit the mother to gain access to employment and other social activities so as to limit the social interaction and the mother at risk of poverty. Socioeconomic status is one of the mother's psychosocial stressors that affect pregnancy outcomes. ${ }^{5}$

Psychosocial stressors triggered by social factors, economic and low education will create the perception of stress. Perception of stress is an early stage of defining acceptable sources of stress by sensory organs to determine the accuracy of the stress response. Mothers who received psychosocial stressors will perceive and respond so as to achieve a new balance (eustress) or cause balance disorders (distress). ${ }^{6}$ Psychological stressors shown to increase HSP70 in the blood on studies with experimental animals and the changes of HSP70 in the blood concentration was reported in several pathological conditions. ${ }^{7}$ Stress to the cells resulted in the increasing number of denatured proteins, thereby also increasing the need HSP70. This increase in protein synthesis in response to stress is used as the defining characteristics of HSP70. ${ }^{8}$ As part of a homeostatic response, stress proteins is a fundamental adaptive response in unicellular and multicellular organisms. Heat shock protein implicated in variety of big phenomena, such as modulation of the immune response, hyperthermia, hyperoxia, ischemia and other changes. ${ }^{9}$
Low cortisol levels will increase the suppressive effect of myocyte protein that caused HSP70 production decreased, impact with the amount of calcium in myocytes, decreased cytoplasmic cAMP and cAMP-dependent protein kinase inactivation. Furthermore phosphorylation and inactivation of myosin chain kinase were not happened, causing uterine muscle contraction did not occur and overdue pregnancy. ${ }^{6}$

Association of endogenous HSP70 led to an inflammatory response marked by increased levels of proinflammatory cytokines in the amniotic fluid and the infiltration of neutrophils and macrophages into the myometrium, cervix and amnion membranes. ${ }^{10,11}$ In addition, $\mathrm{CRH}$ causes activation of macrophages that secrete proinflammatory cytokines. Association of HSP70 and endogenous proinflammatory cytokines cause activation of NF-kB and other proinflammatory transcription factors in the myometrium, and cervical epithelial amnion cells. Activated NF-kB increase the expression of genes that promote myometrial contractility, among other F2 $\alpha$ receptors, gap junction-connexin 43 protein, oxytocin receptor and cyclooxy-genase2 (COX-2). ${ }^{12}$

This study examined the level of HSP70 of mothers with postterm pregnancy and normal pregnancy in Dr. Moewardi Hospital, Surakarta, Central Java.

\section{METHOD}

This study is observational analytic cross-sectional study design. The subjects were 15 women with postterm pregnancy and 30 women with normal aterm pregnancy who meet the inclusion criteria. The samples were obtained from Delivery Room PONEK, Obstetrics Polyclinic of Dr. Moewardi Hospital, Surakarta from January to February 2013. The Inclusion criterias include gestational age of 41 weeks or more, first pregnancy, age between 20-35 years old, married, education of elementary school up to high school and normal pregnancy. The exclusion criterias were women who didn't get married or with impending divorce, unwanted pregnancy, hypertension in pregnancy, genital infection and other accompanying diseases.

Sample size in qualitative research needs to be estimated optimally so that researchers can estimate the parameters accurate, reliable and efficiently. ${ }^{13}$ 
This research were permitted by Dr. Moewardi Surakarta Hospital director and the ethical committee (ethical clearance). The women who met the criteria would receive an explanation and asked for permission to be the subject of this research. The subjects were asked to sign the informed consent. Before the study subjects performed blood sampling, recorded physical data such as patient height, weight, body mass index, left upper arm circumference, systolic and diastolic blood pressure. Blood was drawn from the cubital vein as much as $10 \mathrm{cc}$ and each divided $5 \mathrm{cc}$ for HSP70 examination, Cubital venous blood as much as $5 \mathrm{cc}$ immediately accommodated in a plain tube that has been cooled to a temperature $2-8^{\circ} \mathrm{C}$. Tube is inserted into the blood by way of the flow tube to prevent lysis of blood cells. Once inserted into the tube of blood cold, then the inverted blood until homogeneous. Tube labels written number, name, age, date of birth, sex and address of the patient. Date and time of blood sampling are listed on the label. Tube which had been filled blood inserted into a room temperature $2-8^{\circ} \mathrm{C}$ until blood freeze (samples should not be in contact with an icepack). Blood samples were immediately centrifuged at a speed of 3000 rotations per minute for 15 minutes. Blood serum immediately separated into the sample cup each of $0.3 \mathrm{cc}$. Serum samples given identity, name, date and type of examination. Two samples of each cup as much as $0.3 \mathrm{cc}$ of serum for HSP70 HS examination sent to the Allied Research Department Prodia Tower Jln. Kramat Raya No. 150 ( $3^{\text {rd }}$ floor) in Central Jakarta. Serum should be stored at $-70^{\circ} \mathrm{C}$.

The Independent variable was Heat Shock Protein 70 level and dependent variable was postterm pregnancy. In this study, data was collected, assessed, tabulated and presented in tables. Data was analyzed by $\mathrm{t}$ test.

\section{RESULT}

Two kinds of research data obtained from primigravida, which were controllers data and biological data. Controllers data (age, gestational age, height, weight, education, systolic blood pressure, diastolic blood pressure, hemoglobin, leucocyte numbers, blood sugar while, SGOT, SGPT, ureum, creatinine and protein) was taken one time in research. Biological data (HSP70) was examined once in the study.

In general, the data characteristics of women in both study groups are shown in Table 1 below.
Table 1. Maternal Data Characteristics Postterm and Aterm Pregnancy.

\begin{tabular}{lcccc}
\hline \hline \multicolumn{1}{c}{ Characteristic } & $\begin{array}{c}\text { Post- } \\
\text { term } \\
\text { Mean }\end{array}$ & $\begin{array}{c}\text { Aterm } \\
\text { Mean }\end{array}$ & Total & p \\
\hline Age & 25.2 & 25.7 & 0.534 \\
Education & 1.9 & 2.27 & 0.071 \\
Group of IMT & 23.14 & 23.43 & 0.520 \\
Group of LILA & 23.36 & 23.43 & & 0.160 \\
Group of content HSP70 & 0.40 & 3.94 & $0.000^{*}$ \\
Hemoglobin & $30(50)$ & $30(50)$ & $60(100)$ & 0.899 \\
Leucocytes & $30(50)$ & $30(50)$ & $60(100)$ & 0.116 \\
Blood sugar & $30(50)$ & $30(50)$ & $60(100)$ & 0.815 \\
SGOT & $30(50)$ & $30(50)$ & $60(100)$ & 0.455 \\
SGPT & $30(50)$ & $30(50)$ & $60(100)$ & 0.071 \\
Ureum & $30(50)$ & $30(50)$ & $60(100)$ & 0.169 \\
Creatinine & $30(50)$ & $30(50)$ & $60(100)$ & 0.706 \\
Total of protein & $30(50)$ & $30(50)$ & $60(100)$ & 0.180 \\
Systolic & $30(50)$ & $30(50)$ & $60(100)$ & 0.850 \\
Diastolic & $30(50)$ & $30(50)$ & $60(100)$ & 0.561 \\
\hline \hline
\end{tabular}

Measurement of levels of HSP70 in the postterm pregnancy group and normal pregnancy group serum performed with ELISA method. It appears that blood serum levels of HSP70 postterm pregnancy group is lower than in normal pregnancy.

Results on the distribution of mean HSP70 levels in serum has shown in Table 2. The mean levels of HSP70 in postterm pregnancy group serum was lower (0.40) compared to normal pregnant group (3.94) and the difference was statistically significant $(\mathrm{p}<0.001)$.

Table 2. Distribution of Mean Serum Levels of HSP70 in the KPD Group and Normal Pregnancy Group.

\begin{tabular}{lccc}
\hline \hline \multicolumn{1}{c}{ Group } & $\begin{array}{c}\text { Large } \\
\text { sample (N) }\end{array}$ & $\begin{array}{c}\text { HSP70 levels } \\
\text { mean (ng/ml) }\end{array}$ & $\mathbf{p}$ \\
\hline Normal & 30 & 3.94 & $<0.001$ \\
Postterm & 15 & 0.40 & \\
\hline \hline
\end{tabular}

\section{DISCUSSION}

This study is an observational analytic cross-sectional study design to determine whether there are differences in levels of HSP70 in postterm pregnant women compared to normal pregnant women aterm. The subject of this study is postterm preg- 
nancy and normal pregnancy in the delivery room and Polyclinic Obstetrics and Gynecology dr Moewardi Surakarta from February to March 2013, in accordance with the terms of receipt of samples (inclusion criteria). While the criteria for a normal pregnancy is a pregnancy which the antenatal care during pregnancy until delivery has no complications for both mother and fetus/baby. The number of samples in this study were 45 with 15 sample distribution for postterm pregnancy cases and 30 normal samples for normal pregnancies.

The level of HSP70 in both groups is examined using the ELISA technique. Having obtained the data mean levels of HSP70 in postterm (0.40) and normal pregnancies (3.94 in). It can be seen that there are differences levels of HSP70 in both groups, levels of HSP70 in postterm pregnancy group was lower when compared with normal pregnancy. Based on t test, obtained IK value 95\% between -4.62 to -2.47 . Therefore we conclude that the mean level of HSP70 in premature rupture of membranes was lower than the normal full-term pregnancy and this difference and it was statistically significant.

The role of HSP70 in the incidence of postterm pregnancy has not been studied previously and found no similar studies of scientific publications search. Several factors related to postterm pregnancy such as fetal abnormalities (anencephaly), placental sulfatase enzyme deficiency, no previous delivery and previous postterm pregnancy history. Additionally suspected genetic factors, gender male fetus and redundant mother's body mass index. There is evidence of decreased contractility of the myometrium after gestation of 40 weeks, although still little mechanistic studies about maternal myometrium with postterm pregnancy and most of them are unknown etiology. ${ }^{14}$

In the retrospective cohort study by Denison et al stated that there is a relationship between obesity, length of gestation, the risk of postterm pregnancy and spontaneous labor onset in normal pregnancies. The study concluded that excess maternal body mass index in the first trimester and a significant increase in body mass index during pregnancy is associated with incidence and increased incidence of postterm pregnancy. ${ }^{15}$

Limitations of this study is the limited sample size and cross-sectional research design. To see the changes and the role of HSP70 levels in postterm pregnancy compared to normal pregnancy it is necessary to conduct further research with a cohort study design in order to be studied more in depth in individuals under the same conditions. A cross-sectional study design cannot provide information of HSP70 levels change, but merely gives the ratio of the prevalence of the risk of postterm pregnancy.

\section{CONCLUSION}

HSP70 levels in postterm pregnancy obtained lower levels than in normal full-term pregnancy and this difference was statistically significant.

\section{SUGGESTIONS}

Further research needs to be done with a cohort design and large sample size.

\section{REFERENCES}

1. Price SA, Bernal AL. Uterine quiescence: the role of cyclic AMP in Uterine Contractility Symposium, Experimental Physiology. 2001; 86(2): 265-72.

2. Latendresse G. The interaction between chronic stress and pregnancy: Preterm birth from a biobehavioral perspective, J Midwifery Womens Health. 2009; 54(1): 8-17.

3. Cuningham FG, Gant Leveno, Gilstrap. Parturition; Williams Obstetrics, 22 ${ }^{\text {nd }}$ edition, Appleton and Lange New York. 2005: 176-7.

4. Halloran DR, Cheng YW, Wall TC, Macones GA, Caughey AB. Effect of maternal weight on postterm delivery, J Perinatol. 2012; 32(2): 85-90.

5. Kramer MS, Goulet L, Lydon J, Seguin L, McNamara H, Dassa C, Platt RW et al. Sosio-economic disparities in preterm birth: causal pathways and mechanisms, J Paediat Perinatol Epidemiol. 2001; 15(2): 104-23.

6. Soetrisno. Ekspresi heat shock protein 60, 70, 90 dan kortisol pada persalinan ibu primigravida yang mendapat psikokuratif, Disertasi Program Pascasarjana, Universitas Airlangga, Surabaya. 2009

7. Chaiworapongsa T, Erez O, Kusanovic JP, Vaisbuch E, Mazaki-Tovi S, Gotsch F, Than NG et al. Amniotic fluid heat shock protein 70 concentration in histologic chorioamnionitis, term and preterm parturition, J Mat Fet Neonatal Med. 2008; 21(7): 449-61.

8. Avisar D, Alexy I, Dolja V. Class VIII Myosins Are Required for Plasmodesmatal Localization of a Closterovirus Hsp 70. Homol J Virol. 2008; 82(6): 2836-43.

9. Rodriguez-Dennen F, Martinez-Ocana J, Kawa-Karasik S, Villanueva-Egan L, Reyes-Paredes N, Flisser A, Olivo-Diaz A. Comparison of hemodynamic, biochemical and hematological parameters of healthy pregnant women in the third trimester of pregnancy and the active labor phase, BMC Pregnancy and Childbirth, 2011; 11(33): 1471-2393.

10. Koga K, Mor G. Toll-like receptors at the maternal-fetal interface in normal pregnancy and pregnancy disorders. Am J Reprod Immunol 2010; 63(6): 587-600. 
11. Noguchi T, Sado T, Naruse K, Shigetomi H, Onogi A, Haruta S, Kawaguchi R et al. 2010, Evidence for Activation of tolllike receptor and receptor for advanced glycation end products in preterm birth, Mediat Inflammation. 2010: 1-10.

12. Mendelson CR. Minireview: fetal-maternal hormonal signaling in pregnancy and labor, Mol Endocrinol. 2009; 23(7): 947-54.

13. Murti B. Desain dan ukuran sampel untuk penelitian kuantitatif dan kualitatif di bidang kesehatan, Gadjah Mada University Press, 2010: 108-9.
14. Arrowsmith S, Quenby S, Weeks A, Burdyga T, Wray S. Poor Spontaneous and Oxytocin-Stimulated Contractility in $\mathrm{Hu}-$ man Myometrium from Postdates Pregnancies, J Plose One. 2012; 7(5): 1-11.

15. Denison F, Price J, Graham C, Wild S, Liston W. Maternal obesity, length of gestation, risk of postdates pregnancy and spontaneous onset of labour at term, Bri J Obstet Gynaecol, 2008; 115: 720-5. 